\title{
A new editor and new features for our readers and authors
}

\author{
Robert C. Griggs, MD, Editor-in-Chief; and Kathleen M. Pieper
}

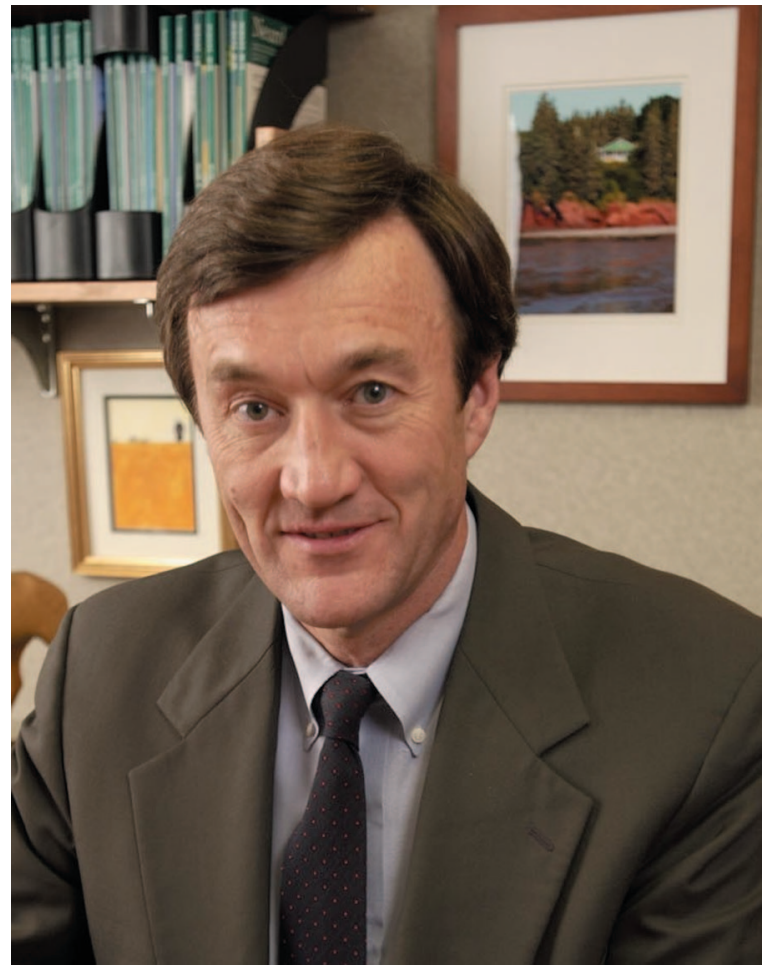

John Noseworthy, MD

Neurology Editor-in-Chief effective January 1, 2007

New Editor-in-Chief named. Dr. Robert Griggs will end his 10-year term as Editor-in-Chief of Neurology in December 2006. Dr. John Noseworthy of the Mayo Clinic College of Medicine in Rochester, Minnesota, has been named as his successor effective January 1, 2007. Dr. Noseworthy received his MD degree from Dalhousie University in Nova Scotia (Canada), interned at the Royal Columbia Hospital in British Columbia, and completed his residency training at Dalhousie University and the University of Western Ontario (London). He studied under a postdoctoral fellowship in immunology at Harvard and was on the staff of the University of Western Ontario from 1983 to 1990. In 1990, he moved to the Mayo Clinic and served as Chair of the Department of Neurology from 1997 until early in 2006. His research focuses on multiple sclerosis and clinical trials. He has just completed his 3-year term as Chair of the American Academy of Neurology (AAN) Sci- ence Committee. He is the editor of the three-volume textbook Neurological Therapeutics: Principles and Practice (2nd edition, Informa Healthcare, 2006) and Fifty Neurologic Cases from Mayo Clinic (Oxford University Press, 2004).

Dr. Noseworthy plans to add new sections to the Journal including "Case Records of Mayo Clinic" and "Clinical Implications of Neuroscience Research." Each of these features will be presented once per month. Case Records will follow the format of the traditional clinical pathologic conference that plays such a large role in resident education in many leading neurologic centers (popularized by the New England Journal of Medicine). Experts in the field will author the discussions. "Clinical Implications of Neuroscience Research" will provide a brief review of a current, basic science research topic and discuss its relevance to clinical practice. The Clinical Implications feature will follow a preplanned annual curriculum and offer CME credits for the reader.

The AAN, the Neurology Editors, Editorial Board, and Editorial Office welcome Dr. Noseworthy.

Changes in the Editorial Board and Editors. We welcome Karen C. Johnston, MD, to the Neurology Editorial Board, effective July 1. Dr. Johnston was Neurology's Resident and Fellow Section Editor. Dr. Mitchell S. Elkind took this Section Editor position on May 1 after Dr. Johnston successfully introduced the section in its first 3-year term. Mitchell S. Elkind, MD, MS, from Columbia University will publish an update on this section and his goals for expanding it in the October 24 issue of Neurology. The Resident and Fellow Editorial team also welcomes the following new members: Irfan Lalani, Christopher Nolte, and Fabio Iwamoto. Neurology invites neurology educators, residents, and fellows to submit articles to this section.

Manuscript submissions. The number of manuscripts we receive continues to increase. In 2005, we received 4,100 manuscripts. In 2004, we received 3,842 submissions and in 2003 we received 3,589 . For 2006, we are on a pace to receive over 4,250 manuscripts. International submissions continue to constitute $65 \%$ to $70 \%$ of submissions. Web access of www.neurology.org has also increased. From 2004 to 
2006 , the total number of online readers increased more than $220 \%$.

\section{Changes and new features.}

CME site. CME Editors Paul Schulz, MD, from Baylor in Houston and Steve Lewis, MD, from RushPresbyterian in Chicago continue to successfully guide our CME program. Our subscribers interested in obtaining CME can now access CME at a new enhanced subsite: http://cme.neurology.org. This site features upgrades including detailed instructions on how to take CME tests, CME articles grouped for easy access, and personal CME history through the "My CME" section.

Past content on www.neurology.org. The full archives of Neurology back to its inception in 1951 have been scanned and will post in late spring 2006 . The articles are posted as pdfs and will be searchable by keyword.

International translations available. Currently, selected articles are translated into Polish for our Polish edition of Neurology. Those translations are now available and attached to the specific article. We will soon also have the Japanese and Italian translations posted. A future initiative is under way to have a link on the home page to all translations grouped by language.

Media reviews added to book review section. Garrett Riggs, Associate Editor and Book Review Editor, notes that the section "Book Reviews" will be changed to "Book and Media Reviews." We welcome reviews of computer or PDA software, Web sites, or CD-ROMs. They should be no longer than 250 words. They should include all pertinent information about the media material including title, authors, editors, date and city of publication, copyright date, and cost. Media reviews are subject to assessment by the Editors. Contact Sandi Moriarity at the Editorial Office for more information (sandi_moriarity@urmc. rochester.edu).

International editions. Submissions from outside of the United States continue to constitute a majority of Neurology submissions (65-70\%). Italy, Germany, and Japan are the top three submitting countries, and we have 10 international Editorial Board members and more than 600 international peer-reviewers. Neurology currently provides free online access to many developing countries. As a reflection of Neurology's increasing presence overseas, Neurology held the first International Editors' Meeting in San Diego this year during the Annual Meeting of the AAN. Organized with the assistance of Zbigniew Wszolek, MD, Polish Editor, the meeting considered our current Italian, Polish, Japanese,

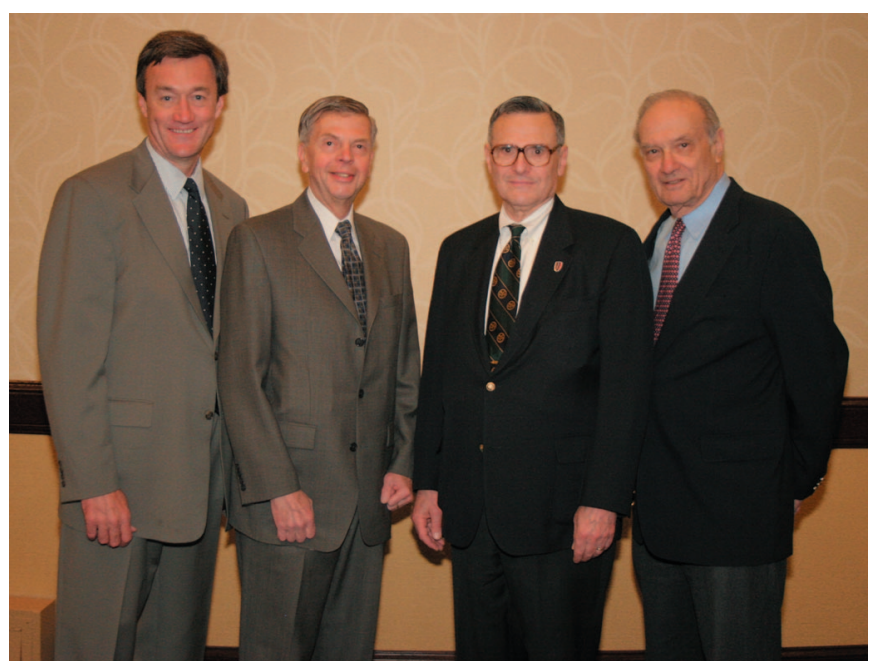

Editors-in-Chief of Neurology (left to right): John Noseworthy, MD (effective 2007); Robert C. Griggs, MD (19962006); Robert B. Daroff, MD (1987-1996); and Lewis P. Rowland, MD (1977-1986).

Turkish, and Spanish editions of the Journal. Chinese, Hungarian, Portuguese, German, Russian, and Korean editions are under development.

Online activation. Most print readers have activated their online subscriptions. To do so, access www.neurology.org and select the "login instructions" link provided on the Help screen. This will lead you to a step-by-step activation process. The online journal includes full text (pdf and html formats) of articles from 1999 forward (1941-1998 available in pdf only), links to PubMed, and extensive search capabilities. Online Neurology includes many features not available in the print version, including Expedited E-Pub articles, rapidly posted Correspondence, CME, videos, Patient Page, Resident and Fellow Page, and supplemental data.

Four Editors-in-Chief of Neurology attend the 2006 Neurology Editorial Board meeting. The two past Editors-in-Chief (L.P. Rowland and R.B. Daroff), the current Editor-in-Chief (R.C. Griggs), and the future Editor-in-Chief (J. Noseworthy) attended the Neurology Editorial Board meeting in San Diego this year. Dr. Rowland is Editor of Neurology Today and is one of the most timely and busiest reviewers for Neurology. Dr. Daroff is Neurology's Scientific Integrity Advisor, reviewing all cases that come into the Neurology Editorial Office including authorship disputes, duplicate publication, plagiarism, and scientific fraud. Neurology's first Editor-inChief was Russell N. DeJong, 1951-1976. 


\section{Neurology}

\section{A new editor and new features for our readers and authors \\ Robert C. Griggs and Kathleen M. Pieper \\ Neurology 2006;67;6-7 \\ DOI 10.1212/01.wnl.0000229468.02136.f6}

\section{This information is current as of July 10, 2006}

\section{Updated Information \&}

Services

Permissions \& Licensing

Reprints including high resolution figures, can be found at: http://n.neurology.org/content/67/1/6.full

Information about reproducing this article in parts (figures,tables) or in its entirety can be found online at:

http://www.neurology.org/about/about_the_journal\#permissions

Information about ordering reprints can be found online:

http://n.neurology.org/subscribers/advertise

Neurology ${ }^{\circledR}$ is the official journal of the American Academy of Neurology. Published continuously since 1951, it is now a weekly with 48 issues per year. Copyright . All rights reserved. Print ISSN: 0028-3878. Online ISSN: 1526-632X.

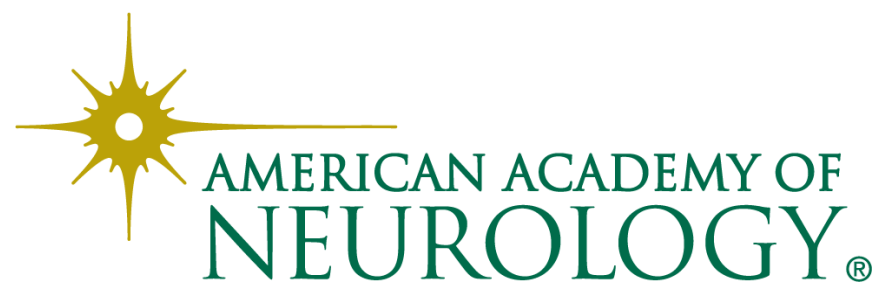

